\title{
Koszty jakości przedsiębiorstw w ujęciu definicyjnym
}

\section{Quality Costs of Companies in Definition Approach}

Streszczenie: Głównym celem artykułu jest przedstawienie najważniejszych definicji kosztów jakości. W pierwszej części autor prezentuje historyczną perspektywę, która przyczyniła się do wzrostu zainteresowania kosztami jakości. Drugi punkt zawiera zestawienie najważniejszych definicji pojęcia kosztów jakości. W trzeciej części autor koncentruje się na różnicach i wspólnych elementach przedstawionych definicji. Obiektem badań są koszty jakości ponoszone przez przedsiębiorstwa we wszystkich fazach procesu produkcyjnego oraz procesu świadczenia usługi. W pracy przeprowadzono krytyczną analizę piśmiennictwa naukowego z zakresu zarządzania jakością, rachunkowości i marketingu oraz zastosowano metody indukcji i dedukcji. Już w latach czterdziestych XX wieku koszty związane z jakością zaczęły odgrywać ważną rolę w przedsiębiorstwach. Wielka rewolucja jakościowa w Japonii, zapoczątkowana przez J.M. Jurana i A.V. Feigenbauma, była bardzo ważnym bodźcem dla rozwoju jakości. Wraz z upływem czasu coraz szersze grono naukowców decydowało się na prowadzenie badań naukowych w obszarze kosztów jakości i rachunku kosztów jakości. Również liczne doświadczenia z praktyki gospodarczej przyczyniły się do pojawienia się nowych określeń pojęcia kosztów jakości. Efektem przeglądu definicji będzie uporządkowanie wiedzy na temat kosztów jakości jako przedmiotu badań nauk o zarządzaniu.

Abstract: The main purpose of the article is to present the most important definitions of quality costs. In the first part, the author presents a historical perspective, which contributed to the increase in interest in quality costs. The second part contains a summary of the most important definitions of the concept of quality costs. In the third part, the author focuses on the differences and common elements of the definitions presented. The object of research is the quality costs incurred by companies in all phases of the production process and the service delivery process. The work involved a critical analysis of scientific literature in the field of quality management, accounting and marketing, and methods of induction and deduction. Already in the 1940s, quality-related costs began to play an important role in companies. A great quality revolution in Japan initiated by J.M. Jurana and A.V. Feigenbaum was a very important stimulus for the development of quality. With the passage of time, an increasing number of scientists decided to conduct scientific research in the area of quality costs and quality costs calculations. Numerous experience in business practice has also contributed to the emergence of new definitions of the concept of quality costs. The effect of the definition review will be to organise the knowledge on quality costs as a subject of research in management sciences.

Słowa kluczowe: definicja; historyczna perspektywa; jakość; koszty jakości

Key words: definition; historical perspective; quality; quality costs 
Otrzymano: 7 listopada 2018

Received: 7 November 2018

Zaakceptowano: 15 stycznia 2019

Accepted: 15 January 2019

Sugerowana cytacja / Suggested citation:

Sadkowski, W. (2019). Koszty jakości przedsiębiorstw w ujęciu definicyjnym. Prace Komisji Geografii Przemysłu Polskiego Towarzystwa Geograficznego, 33(1), 80-88. https://doi.org/10.24917/20801653.331.6

\section{WSTĘP}

Koszty stanowią integralną część prowadzenia każdej działalności gospodarczej (Sadkowski, 2017). Przedsiębiorstwa konkurują ze sobą na płaszczyźnie jakości, ceny, czasu wytworzenia, a także dystrybucji wyrobu czy usługi. Sprostanie rosnącym wymaganiom konsumenckim możliwe jest poprzez określanie, mierzenie i kontrolowanie wszystkich kosztów związanych z jakością (Chiu, Su, 2010; Raßfeld, Behmer, Durlich, Jochem, 2015).

Celem artykułu jest przedstawienie najważniejszych definicji kosztów jakości, które były prezentowane przez teoretyków i praktyków zarządzania jakością oraz rachunkowości.

W pierwszym podrozdziale ujęte zostały pierwsze historyczne wzmianki o kosztach jakości, który stanowiły początek zainteresowania nimi. Główna część artykułu zawiera zestawienie najważniejszych definicji pojęcia kosztów jakości. Następnie autor koncentruje się na różnicach i wspólnych elementach przedstawionych definicji.

\section{HISTORYCZNA PERSPEKTYWA}

Pierwsze informacje o kosztach jakości pojawiły się w Stanach Zjednoczonych w latach czterdziestych XX wieku (Hellman, Liu, 2013). W przedsiębiorstwach zapewniających dostawy sprzętu wojskowego dla aliantów podczas drugiej wojny światowej wystąpił problem wysokiej wadliwości produkowanego zaopatrzenia, sięgający aż $80 \%$. Główną przyczyną nieprawidłowości było nieposiadanie wykwalifikowanej kadry specjalistów. Największe trudności pojawiały się w identyfikacji kosztów jakości. Priorytetem było znalezienie sposobu na likwidację wad. Przedsiębiorstwa zainicjowały badania i kontrole produkcji, co dało początek kosztom oceny. Również w tym okresie wytworzyło się pojęcie zewnętrznych kosztów jakości (wady wykryte przez odbiorców zewnętrznych) oraz wewnętrznych kosztów jakości (Szymula, 2005).

Lata pięćdziesiąte XX wieku przyniosły niespotykane dotąd zainteresowanie tematyką kosztów jakości. Główny ośrodek badań wykształcił się w Japonii, gdzie swoje idee realizowali amerykańscy uczeni J.M. Juran (1974) i W.E. Deming (1950). Pojęcie kosztów jakości (quality costs) zostało wprowadzone do literatury przedmiotu przez J.M. Jurana i A.V. Feingenbauma. Pierwszy z nich przyrównał koszty jakości do kopalni złota, którą miały być korzyści powstające w wyniku wysokiej jakości produktów. Sterowanie jakością będzie możliwe tylko wtedy, gdy zostanie ona zmierzona. Instrumentem do jej pomiaru stały się koszty jakości (McLaughlin, 1995).

Książki autorstwa A.V. Feigenbauma (1961) i J.M. Jurana (1974) opisywały współpracę wszystkich pracowników w przedsiębiorstwie przy wykorzystaniu kosztów jakości: kosztów oceny, kosztów zapobiegania i braków. Natomiast publikacja 
Amerykańskiego Stowarzyszenia Sterowania Jakością z 1967 roku sklasyfikowała koszty jakości jako: koszty działalności zapobiegawczej, koszty oceny jakości, straty na brakach wewnętrznych oraz straty na brakach zewnętrznych (Wood, 2013).

Rosnąca presja na redukcję kosztów i poprawę wyniku finansowego przyczyniła się do wzrostu zainteresowania przedsiębiorstw kosztami związanymi z jakością. Ważnym wydarzeniem 1987 roku było wprowadzenie w wielu krajach norm ISO serii 9000, zawierających modele zapewnienia jakości i zarządzania nią oraz założenia do tworzenia systemów jakości przedsiębiorstw (Lisiecka, 2002).

\section{PRZEGLĄD DEFINICJI KOSZTóW JAKOŚCI}

Pojęcie kosztów jakości nie jest dokładnie i jednoznacznie określone. M. Ciechan-Kujawa (2005) wyjaśnia, że ma to związek z różnicami w podejściu do jakości oraz przenikaniem się obszarów działań jakościowych z innymi procesami.

Autor przygotował przegląd najważniejszych definicji kosztów jakości i zamieścił je w tab. 1. Kluczem porządkującym zestawienie był podział chronologiczny od pierwszej definicji J.M. Jurana (1951) do definicji K. Szczepańskiej (2017).

Tab. 1. Przegląd definicji pojęcia kosztów jakości

\begin{tabular}{|c|c|c|}
\hline Autor & Rok & Treść definicji \\
\hline J.M. Juran & 1951 & Instrument służący do pomiaru jakości. „Złoto kopalni” (Juran, 1951) \\
\hline A.V. Feigenbaum & 1961 & $\begin{array}{l}\text { Koszty związane z działaniami projakościowymi uwzględniającymi: } \\
\text { prewencję, ocenę badania i kontrolę, skutki błędów, związane z całym } \\
\text { cyklem życia produktu (Feigenbaum, 1961) }\end{array}$ \\
\hline $\begin{array}{l}\text { American Society for } \\
\text { Quality Control }\end{array}$ & 1967 & $\begin{array}{l}\text { Zasoby wykorzystywane do działań, które zapobiegają niskiej jakości, } \\
\text { do działań związanych z oceną jakości produktów lub usług, a także } \\
\text { wynik wewnętrznych i zewnętrznych awarii. Posiadanie takich danych } \\
\text { pozwala organizacji oszacować potencjalne oszczędności, które można } \\
\text { uzyskać przy wprowadzeniu ulepszeń procesowych (ASQC,1971) }\end{array}$ \\
\hline J.M. Groocock & 1974 & $\begin{array}{l}\text { Koszty poniesione na wadliwą produkcję oraz te, które nie } \\
\text { wystąpiłyby, gdyby nie podejmowano działań zapewniających jakość } \\
\text { i gdyby nie powstały żadne usterki i wady (Groocock, 1974) }\end{array}$ \\
\hline F. Nixon & 1974 & $\begin{array}{l}\text { Koszty uzyskania pewności, że konsument otrzyma tylko te produkty, } \\
\text { które zostały wykonane zgodnie z wymaganiami (Nixon, 1974) }\end{array}$ \\
\hline P. Crosby & 1979 & $\begin{array}{l}\text { Jakość nic nie kosztuje, ale kosztowny jest brak jakości, czyli } \\
\text { niewłaściwe wykonanie pracy za pierwszym razem (Crosby, 1979) }\end{array}$ \\
\hline S. Sojak & 1981 & $\begin{array}{l}\text { Koszty tych operacji gospodarczych, które są dokonywane w ramach } \\
\text { kompleksowego systemu sterowania jakością i mają na celu poprawę } \\
\text { dotychczasowej jakości produkowanych wyrobów, obniżenie kosztów } \\
\text { i strat wywołanych wadliwą produkcją oraz koszty i straty z niej } \\
\text { wynikające (Sojak, 1981) }\end{array}$ \\
\hline T. Borys & 1982 & $\begin{array}{l}\text { Ponoszone nakłady lub utracone korzyści, które są wynikiem } \\
\text { niedoskonałych działań (Borys, 1982) }\end{array}$ \\
\hline B. Oyrzanowski & 1984 & $\begin{array}{l}\text { Nakłady ponoszone na uzyskanie określonego poziomu jakości, } \\
\text { analizę kosztów, które wpływają na uzyskanie określonego poziomu } \\
\text { jakości, oraz działania mające zminimalizować koszty jakości } \\
\text { w przedsiębiorstwie. Określane jako metoda sterowania jakością } \\
\text { (Oyrzanowski, 1984) }\end{array}$ \\
\hline Norma ISO 8402 & 1986 & $\begin{array}{l}\text { Wydatki poniesione na zapobieganie defektom i działania związane } \\
\text { z oceną oraz straty spowodowane wewnętrznymi i zewnętrznymi } \\
\text { błędami (PN-ISO, 1996) }\end{array}$ \\
\hline
\end{tabular}




\begin{tabular}{|c|c|c|}
\hline G. Taguchi & 1986 & $\begin{array}{l}\text { Każde odchylenie cech produktu od wymagań i oczekiwań klienta } \\
\text { jest stratą i przyczynia się do obniżenia poziomu jego satysfakcji oraz } \\
\text { pogorszenia obrazu producenta (Taguchi, 1986) }\end{array}$ \\
\hline J.M. Juran i F.M. Gryna & 1989 & $\begin{array}{l}\text { Pewne wydatki związane z zapewnieniem produktowi przydatności } \\
\text { do użytku (Juran, Gryna, 1989) }\end{array}$ \\
\hline J. Bank & 1992 & $\begin{array}{l}\text { Termin kosztów jakości dotyczy wszystkich kosztów związanych } \\
\text { z jakością (Bank, 1992) }\end{array}$ \\
\hline Y.S. Chen i K. Tang & 1992 & $\begin{array}{l}\text { Koszty jakości to koszty inspekcji i zapobiegania, a także koszty } \\
\text { poniesionych działań naprawczych i niedoskonałej jakości (Chen, } \\
\text { Tang, 1992) }\end{array}$ \\
\hline $\begin{array}{l}\text { J.J. Dahlgaard, G.K. Kanji } \\
\text { i K. Kristensen }\end{array}$ & 1992 & $\begin{array}{l}\text { Jeden z najważniejszych aspektów rozwoju systemów zarządzania } \\
\text { jakością (Dahlgaard, Kanji, Kristensen, 1992) }\end{array}$ \\
\hline E. Skrzypek & 1993 & $\begin{array}{l}\text { Miara efektywności działań zapewniających funkcjonowanie } \\
\text { systemu zarządzania jakością. Są syntezą wszystkich kosztów } \\
\text { operacyjnych związanych z zapewnieniem jakości. To także narzędzie } \\
\text { umożliwiające ukazanie słabych punktów w procesach podstawowych } \\
\text { i pomocniczych organizacji (Skrzypek, 1993) }\end{array}$ \\
\hline Norma ISO 9004-3 & 1994 & Środki do oceny efektywności systemu jakości (PN-ISO, 1996) \\
\hline J. Pike i R. Barnes & 1996 & $\begin{array}{l}\text { Wynik odchyleń, które występują w systemach i procesach. Nakłady } \\
\text { poniesione na monitoring, kontrolę i zapobieganie powstawaniu } \\
\text { planowanych i nieplanowanych odchyleń (Pike, Barnes, 1996) }\end{array}$ \\
\hline K. Lisiecka & 1997 & $\begin{array}{l}\text { Ważny wskaźnik diagnostyczny słabych stron przedsiębiorstwa } \\
\text { m.in. w działach: zaopatrzeniu, montażu, kontroli i badaniach. Są } \\
\text { syntetyczną informacją dla kierownictwa firmy o stopniu racjonalizacji } \\
\text { działań systemu zapewnienia jakości. Wyrażają skwantyfikowany } \\
\text { cel zapewnienia jakości, który wiąże się z doborem takiej struktury } \\
\text { nakładów, przy której suma strat i kosztów na zapewnienie } \\
\text { odpowiedniej jakości będzie najmniejsza (Lisiecka, 1997) }\end{array}$ \\
\hline W.A. Nowak & 1997 & $\begin{array}{l}\text { Koszty dostosowania jakości do potrzeb i oczekiwań klienta, które } \\
\text { obejmują prewencję i ocenę, a także koszty niedostosowania jakości } \\
\text { wynikające z niedociągnięć wytwarzania i skutków zewnętrznych } \\
\text { (Nowak, 1997) }\end{array}$ \\
\hline T. Wawak & 1997 & $\begin{array}{l}\text { Nieodłączna część systemu Total Quality Management. Powstają } \\
\text { one w całym cyklu życia produktu - od momentu podjęcia decyzji } \\
\text { o rozpoczęciu produkcji dobra aż po jego likwidację i są określane jako } \\
\text { tzw. społeczne koszty jakości (Wawak, 1997) }\end{array}$ \\
\hline $\begin{array}{l}\text { F.M. Bland, J. Maynard } \\
\text { i D.W. Herbery }\end{array}$ & 1998 & $\begin{array}{l}\text { Koszty będące różnicą pomiędzy rzeczywistym kosztem wytworzenia } \\
\text { a kosztem, który powstałby, gdyby nie było żadnych awarii systemów } \\
\text { i błędów pracowników (Bland, Maynard, Herbery, 1998) }\end{array}$ \\
\hline J. Campanella & 1999 & $\begin{array}{l}\text { Różnica pomiędzy rzeczywistym kosztem produktu lub usługi, } \\
\text { a kosztem, który powstałby w idealnej sytuacji, w której nie występują } \\
\text { żadne braki (tzn. nie pojawiają się: usługi poniżej norm konsumentów, } \\
\text { wadliwe produkty czy defekty w procesie produkcyjnym) } \\
\text { (Campanella, 1999) }\end{array}$ \\
\hline $\begin{array}{l}\text { S.K. Krishnan, A. Agus } \\
\text { i N. Husain }\end{array}$ & 2000 & $\begin{array}{l}\text { Koszty ponoszone w celu uniknięcia braków w jakości i niespełnienia } \\
\text { wymagań klientów, a także koszty, które powstają, gdy nie są } \\
\text { spełnione wymagania klientów dotyczące jakości (Krishnan, Agus, } \\
\text { Husain, 2000) }\end{array}$ \\
\hline Norma ISO 9000 & 2000 & $\begin{array}{l}\text { Czynnik ekonomiczny, który wpływa na jakość. Koszty ponoszone } \\
\text { w związku z zagwarantowaniem i zapewnieniem zadowalającej } \\
\text { jakości, a także jako straty ponoszone z powodu nieosiągnięcia } \\
\text { zadowalającej jakości (PN-EN ISO, 2001) }\end{array}$ \\
\hline $\begin{array}{l}\text { G. Giakatis, T. Enkawa } \\
\text { i K. Washitani }\end{array}$ & 2001 & $\begin{array}{l}\text { Koszty wszystkich działań podejmowanych w celu spełnienia przez } \\
\text { dany produkt określonych wymagań (Giakatis, Enkawa, Washitani, } \\
\text { 2001) }\end{array}$ \\
\hline N. Chiadamrong & 2003 & $\begin{array}{l}\text { Całkowite koszty jakości są różnicą między rzeczywistymi } \\
\text { kosztami produktu/usługi a kosztem, gdy jakość byłaby doskonała } \\
\text { (Chiadamrong, 2003) }\end{array}$ \\
\hline
\end{tabular}




\begin{tabular}{|l|l|l|}
\hline Z. Zymonik & 2003 & $\begin{array}{l}\text { Wyrażone w jednostkach pieniężnych zużycie zasobów na } \\
\text { wytworzenie wartości dla klienta, którą on zaakceptuje, oraz jako } \\
\text { wartościowa utrata tych zasobów. Miara oceny stopnia realizacji zasad } \\
\text { odpowiedzialności za jakośc produktu w strategii przedsiębiorstwa } \\
\text { (Zymonik, 2003) }\end{array}$ \\
\hline A.R. Mukhopadhyaya & 2004 & $\begin{array}{l}\text { Koszty związane z zapobieganiem, stwierdzaniem i korygowaniem } \\
\text { wadliwej pracy (Mukhopadhyaya, 2004) }\end{array}$ \\
\hline J. Gryc & 2004 & $\begin{array}{l}\text { Nakłady, które są ponoszone na uzyskanie oczekiwanego poziomu } \\
\text { jakości oraz jako koszty wynikające z braku oczekiwanego poziomu } \\
\text { jakości, czyli usterek i wszystkich ich konsekwencji (Gryc, 2004) }\end{array}$ \\
\hline S.M.H. Collin & 2007 & $\begin{array}{l}\text { Koszty ponoszone, gdy wyprodukowane towary lub świadczone usługi } \\
\text { nie spełniają norm jakościowych (Collin, 2007) }\end{array}$ \\
\hline V. Kajdan & 2007 & $\begin{array}{l}\text { Różnica pomiędzy kosztem idealnym a realnym kosztem (Kajdan, } \\
\text { 2007) }\end{array}$ \\
\hline D.C. Wood & 2007 & $\begin{array}{l}\text { Koszty związane zarówno z osiągnięciem, jak i z brakiem pożądanego } \\
\text { poziomu jakości usług/produktów (Wood, 2007) }\end{array}$ \\
\hline $\begin{array}{l}\text { L. Weinstein, R.J. } \\
\text { Vokurka i G.A. Graman }\end{array}$ & 2011 & $\begin{array}{l}\text { Są finansową miarą, która wyraża istotne informacje w języku } \\
\text { zarządzania (Weinstein, Vokurka, Graman, 2009) }\end{array}$ \\
\hline L.A. Sedevich Fons & $\begin{array}{l}\text { Koszty jakości to wielkość pieniędzy, z których zrezygnowała firma } \\
\text { (utraciła je, wydała je lub nie uzyskała) na skutek nieefektywności } \\
\text { lub nieskuteczności podczas prowadzonych działań rozwojowych } \\
\text { (Sedevich Fons, 2011) }\end{array}$ \\
\hline K. Szczepańska & $\begin{array}{l}\text { Koszty niespełnienia zidentyfikowanych (wyspecyfikowanych) } \\
\text { wymagań klientów (wewnętrznych i zewnętrznych) przedsiębiorstwa } \\
\text { (Szczepańska, 2017) }\end{array}$ \\
\hline
\end{tabular}

Źródło: opracowanie własne

Tabela przeglądowa prezentuje ewolucję pojęcia kosztów jakości. Od postrzegania ich jako instrumentu pomiarowego jakości, przez traktowanie jako wszystkich wydatków na zapewnienie odpowiedniej jakości, aż do ujmowania ich jako kosztów niespełnienia wymagań klientów. Prawie $1 / 3$ określeń powstała w latach dziewięćdziesiątych XX wieku, a ponad $1 / 3$ w pierwszej dekadzie XXI wieku. Może to świadczyć o rosnącym zainteresowaniu kosztami jakości na przełomie lat dziewięćdziesiątych XX wieku i pierwszej dekady XXI wieku.

Autor dostrzega wspólne elementy różnych ujęć definicyjnych. F.M. Bland, J. Maynard i D.W. Herbery, J. Campanella, P. Crosby, Y.S. Chen. i K. Tang, J.M. Groocock, S.K. Krishnan, A. Agus i N. Husain, D.C. Wood oraz normy ISO uznają aspekt niedoskonałości i powstających wad produktów/usług. Badacze podkreślają, że jednym z celów każdej jednostki gospodarczej powinno być bezbłędne działanie (Groocock 1974; Crosby, 1979). Koszty jakości traktowane są przez nich jako nakłady przeznaczane na osiągnięcie zakładanego poziomu jakości, występujące we wszystkich sferach realizacji produktu (Feigenbaum, 1961; Borys, 1982; Oyrzanowski, 1984; Wawak, 1997; Zymonik, 2003; Gryc, 2004). Dotyczą działań związanych z zapobieganiem, stwierdzaniem i korygowaniem wadliwej pracy, a ich struktura jest określona (Feigenbaum, 1961; ASQC, 1971; Sojak, 1981; Chen, Tang, 1992; Pike, Barnes, 1996; Nowak, 1997; Mukhopadhyaya, 2004). W definicjach można zauważyć przenikanie się obszarów działań jakościowych z innymi procesami realizowanymi w przedsiębiorstwie (Skrzypek, 1993; Pike, Barnes, 1996). Badacze podkreślają, że koszty te służą jako narzędzie do pomiaru jakości produktów/usług i sterowania nią (Juran, 1951; Oyrzanowski, 1984). To także zasobne źródło do obniżenia całkowitych kosztów produkcji. Nieosiągnięcie satysfakcjonującego poziomu jakości przyczynia się do generowania strat i wad 
(m.in. normy PN-ISO, 1996; PN-EN ISO, 2001; Collin, 2007), dlatego też pojawia się nacisk na wytwarzanie produktów/świadczenie usług pozbawionych wad. Koszty jakości określane są również jako różnica między rzeczywistym kosztem wytworzenia a kosztem, który powstałby, gdyby nie było żadnych awarii i błędów (Bland, Maynard, Herbery, 1998; Campanella, 1999; Chiadamrong, 2003; Kajdan, 2007).

Odmienne definiują koszty jakości L. Weinstein, R.J. Vokurka i G.A. Graman, a także G. Taguchi, J.J. Dahlgaard, G.K. Kanji i K. Kristensen oraz K. Lisiecka. W ich ocenie koszty te są ważnym wskaźnikiem diagnostycznym (Lisiecka, 1997), a także finansową miarą wyrażającą istotne informacje (Weinstein, Vokurka, Graman, 2009), która stanowi ważny aspekt rozwoju systemów zarządzania jakością (Dahlgaard, Kanji, Kristensen, 1992). Kosztem jakości jest każde odchylenie od wymagań klienta określane jako strata (Taguchi, 1986) oraz niespełnienie zidentyfikowanych wymagań klientów (Szczepańska, 2017).

Dla specjalistów z zakresu zarządzania jakością koszty jakości są elementem, wyodrębnioną częścią kosztów własnych wytworzenia, która może stanowić zasobne źródło stosowane do obniżenia łącznych kosztów produkcji. Natomiast dla ekonomistów koszty jakości mogą oznaczać „sumę kosztów poniesionych na wytworzenie określonego produktu o określonej jakości, spełniającej wymagania i oczekiwania klienta" (Balon, 2006: 15). Koszty jakości można też zdefiniować jako „wszystkie wydatki służące utrzymaniu, zapewnieniu i poprawie poziomu jakości produktów i usług, jaki jest przez klienta oczekiwany lub został z nim wiążąco ustalony" (Fajczak-Kowalska, 2004: 33).

Przedstawione w tab. 1 definicje kosztów jakości potwierdzają brak jednolitej wersji tego pojęcia. Różnorodność jest skutkiem stosowania różnych podejść do jakości przez badaczy reprezentujących nauki o zarządzaniu i jakości oraz ekonomię i finanse. Czy jest możliwe pogodzenie interesów zarządzania i ekonomii oraz jakości i finansów? Wydaje się, że tak. Elementem łączącym wszystkie definicje w sposób bezpośredni lub pośredni jest klient i jego postrzeganie jakości zakupionego produktu lub wyświadczonej usługi.

Przedsiębiorstwo to zbiór procesów, które prowadzą do stworzenia produktu lub usługi. Na każdym etapie realizacji procesu mogą wystąpić koszty związane z jakością. W oparciu o dwa założenia: obecność klienta oraz uznanie organizacji jako zbioru procesów, autor proponuje własną definicję kosztów jakości. Koszty jakości są to wszystkie wydatki ponoszone na zapewnienie odpowiedniej jakości w realizowanych procesach oraz wydatki, które ponosi przedsiębiorstwo, gdy nie jest zapewniona odpowiednia jakość realizowanych procesów. Najważniejszym miernikiem jakości procesów jest klient i jego satysfakcja.

\section{ZAKOŃCZENIE}

Początki tematyki kosztów jakości datuje się na lata czterdzieste XX wieku. Szczególny rozkwit nastąpił w czasach wielkiej japońskiej rewolucji jakościowej, której ojcami byli J.M. Juran i W.E. Deming. Ważnym wydarzeniem historycznym było również wdrożenie w wielu krajach Ameryki, Azji i Europy międzynarodowych norm ISO.

W literaturze przedmiotu występują liczne definicje pojęcia kosztów jakości. Pierwsze pojawiły się już w latach pięćdziesiątych XX wieku, a ostatnie to druga dekada XXI wieku. 
Wspólne cechy charakterystyczne tego pojęcia to m.in. aspekt niedoskonałości, wady produktów i usług czy bezbłędne działanie jako cel każdej jednostki gospodarczej. Wielu autorów traktuje koszty jakości jako nakłady, które są ponoszone na osiągnięcie zakładanego poziomu jakości.

Do najważniejszych różnic w definiowaniu należą podejścia traktujące koszty jakości jako ważny wskaźnik diagnostyczny, finansową miarę wyrażającą istotne informacje, aspekt rozwoju systemów zarządzania jakością oraz stratę. Różnice odnoszą się zarówno do zakresu, jak i do treści tych kosztów.

Zebrane i przedstawione w artykule różnorodne definicje kosztów jakości świadczą o braku jednolitego, uniwersalnego określenia tego terminu. Autor proponuje własną definicję kosztów jakości opartą na założeniu, że przedsiębiorstwo jest zbiorem realizowanych procesów, a miernikiem ich jakości jest zadowolenie klienta.

Zaprezentowany przegląd kosztów jakości stanowi wprowadzenie do ich postrzegania i stosowania w przedsiębiorstwach. Kolejne badania powinny dotyczyć percepcji kosztów jakości przez przedsiębiorców oraz wykorzystywania rachunku kosztów jakości do optymalizacji kosztów jakości.

\section{Literatura \\ References}

ASQC (1971). Quality costs: What and how (2nd ed.). Milwaukee: ASQC Quality Press.

Balon, U. (2006). Przegląd wybranych modeli klasyfikacji kosztów jakości. Problemy Jakości, 6, 15-19.

Bank, J. (1992). The Essence of Total Quality Management. London: Prentice Hall.

Bland, F.M., Maynard, J., Herbery, D.W. (1998). Quality costing of an administrative proces. The TQM Magazine, 10(5), 367-377.

Borys, T. (1982). Uwarunkowania ekonomiczno-społeczne analizy kosztów a samofinansowanie się przedsiębiorstw. Kwalitologia. Not Gdańsk, 9, 38.

Campanella, J. (1999). Principles of quality costs. Principles, Implementation, and Use. Milwaukee: ASQC Quality Press.

Chen, Y.S., Tang, K. (1992). A pictorial approach to poor-quality. IEEE Transactions on Engineering Management, 39(2), 149-157.

Chiadamrong, N. (2003). The development of an economic quality cost model. TQM \& Busines Excellence, 14(9), 999-1014.

Chiu, Y., Su, D. (2010). Considering quality cost, time-value of money, and proces quality improvement fuction in the economic product quantity model. Journal of the Chinese Institute of Industrial Engineers, 27(4), 249-259.

Ciechan-Kujawa, M. (2005). Rachunek kosztów jakości. Kraków: Oficyna Ekonomiczna.

Collin, S.M.H. (2007). Dictionary of accounting. A\&C Black Publishers Ltd.

Crosby, P. (1979). Quality is free. New York: McGraw-Hill.

Dahlgaard, J.J., Kanji, G.K., Kristensen, K. (1992). Quality and Economic Development Project. Total Quality Management, 3(1), 115-118.

Deming, W.E. (1950). Elementary Principles of the Statistical Control of Quality. JUSE.

Fajczak-Kowalska, A. (2004). Koszty jakości oraz ich rachunek. Problemy Jakości, 8, 33-35.

Feigenbaum, A.V. (1961). Total Quality Control. New York: Mc Graw-Hill.

Giakatis, G., Enkawa, T., Washitani, K. (2001). Hidden quality costs and the distinction between quality cost and quality loss. Total Quality Management, 12(2), 179-190.

Groocock, J.M. (1974). The Cost of Quality. London: Pitman Publishing.

Gryc, J. (2004). Koszty jakości i ich liczenie w przedsiębiorstwie. Problemy Jakości, 3, 22-24.

Hellman, P., Liu, Y. (2013). Development of quality management systems: how have disruptive technological innovations in quality management affected organizations? Quality Innovation Prosperity, 17(1), 104-119. 
Juran, J.M. (1951). Quality Control Handbook. New York: McGraw-Hill.

Juran, J.M. (1974). Quality Control Handbook. New York-Toronto-London: Mc Graw Hill Book Company.

Juran, J.M., Gryna, F.M. (1989). Jakość, projektowanie, analiza. Warszawa: Polskie Wydawnictwo Ekonomiczne.

Kajdan, V. (2007). Why Quality, Cost and Business Excellence are Inseparable. Total Quality Management, 18(1-2), 147-152.

Krishnan, S.K., Agus, A., Husain, N. (2000). Cost of quality: The hidden costs. Total Quality Management, 6, 844-848.

Lisiecka, K. (1997). Rachunek kosztów jakości - narzędziem obniżki kosztów własnych wytworzenia. W: T. Wawak (red.). Klub Polskie Forum ISO 9000. Warszawa, 36-50.

Lisiecka, K. (2002). Kreowanie jakości. Uwarunkowania-strategie-techniki. Katowice: Wydawnictwo Akademii Ekonomicznej w Katowicach.

McLaughlin, G.C. (1995). Total Quality in research and development. Delray Beach: St. Lucie Press.

Mukhopadhyaya, A.R. (2004). Estimation of Cost of Quality in an Indian Textile Industry for Reducing Cost of Non-conformance. Total Quality Management \& Business Excellence, 15(2), $229-234$.

Nixon, F. (1974). Jakość i niezawodność a zarzq̨dzanie przedsiębiorstwem. Warszawa: Polskie Wydawnictwo Ekonomiczne.

Nowak, W.A. (1997). Rachunek kosztów jakości w zarządzaniu. W: A. Jarugowa, W.A. Nowak, A. Szychta. Zarządzanie kosztami w praktyce światowej. Gdańsk, ODDK, 87-109.

Oyrzanowski, B. (1984). Koszty jakości. Mała encyklopedia jakości. Warszawa: Polskie Wydawnictwo Ekonomiczne.

Pike, J., Barnes, R. (1996). TQM in Action. London.

PN-EN ISO 9000:2001 (2001). Systemy zarządzania jakościq - Podstawy i terminologia. Warszawa: Polski Komitet Normalizacyjny.

PN-ISO 8402:1996 (1996). Zarzq̨dzanie jakościq̨ i zapewnienie jakości - Terminologia. Warszawa: Polski Komitet Normalizacyjny.

PN-ISO 9004-3:1996 (1996). Zarzq̨dzanie jakościq i elementy system jakości - Wytyczne dotyczące materiałów wytwarzanych w procesach ciagłych. Warszawa: Polski Komitet Normalizacyjny.

Raßfeld, C., Behmer, F., Durlich, M., Jochem, R. (2015). Do qualiy costs still matter? Total Quality Management \& Business Excellence, 26(9-10), 1071-1082.

Sadkowski, W. (2017). Determinanty struktury kosztów jakości w przedsiębiorstwach usługowych. W: Z. Luty, M. Krasiński (red.). Rachunkowość w zarządzaniu. Wrocław: Wydawnictwo Uniwersytetu Ekonomicznego we Wrocławiu, 72-82.

Sedevich Fons, L.A. (2011). Measuring economic effects of quality management sytems. The TQM Journal, 23(4), 461-462.

Skrzypek, E. (1993). Zarządzanie przez jakość w przedsiębiorstwie. Lublin: Polskie Towarzystwo Ekonomiczne.

Sojak, S. (1981). Termin „koszty jakości” w literaturze ekonomicznej. Zeszyty Teoretyczne Rady Naukowej, 5, 47-69.

Szczepańska, K. (2017). Podstawy zarządzania jakościq. Warszawa: Oficyna Wydawnicza Politechniki Warszawskiej.

Szymula, M. (2005). Rola kosztów w zarządzaniu przedsiębiorstwem. Problemy Jakości, 10, 40-41.

Taguchi, G. (1986). Introduction to Quality Engineering: Designing Quality into Products and Processes. Tokio: Asian Productivity Organization.

Wawak, T. (1997). Koszty jakości. W: T. Wawak (red.). Koszty i korzyści wdrażania systemu jakości w przedsiębiorstwie. Warszawa: Klub Polskie Forum ISO 9000, 141-143.

Weinstein, L., Vokurka, R.J., Graman, G.A. (2009). Cost of quality and maintenance: Improvement approaches. Total Quality Management, 20(5), 497-507.

Wood, D.C. (2007). The executive guide to understanding and implementing quality cost programs: reduce operating expenses and increase revenue. Milwaukee: ASQ Quality Press.

Wood, D.C. (2013). Principles of quality costs. Financial measures for strategic implementation of quality management. Milwaukee: ASQ Quality Press.

Zymonik, Z. (2003). Koszty jakości w zarzq̨dzaniu przedsiębiorstwem. Wrocław: Oficyna Wydawnicza Politechniki Wrocławskiej. 
Wojciech Sadkowski, mgr, Uniwersytet Jagielloński, Wydział Zarządzania i Komunikacji Społecznej, Instytut Ekonomii, Finansów i Zarządzania, Katedra Rachunkowości Międzynarodowej. Zainteresowania badawcze autora: rachunek kosztów jakości, rachunkowość zarządcza, bankowość korporacyjna, sektor małych i średnich przedsiębiorstw, upadłość przedsiębiorstw.

Wojciech Sadkowski, M.Sc., Jagiellonian University, Faculty of Management and Social Communication, Institute of Economics, Finance and Management, Department of International Accounting. His research interests include: quality costs calculation, managerial accounting, corporate banking, small and medium enterprises, company bankruptcy.

\section{ORCID 0000-0003-2757-6643}

\section{Adres/address:}

Uniwersytet Jagielloński Wydział Zarządzania i Komunikacji Społecznej Instytut Ekonomii, Finansów i Zarządzania Katedra Rachunkowości Międzynarodowej ul. prof. S. Łojasiewicza 4, 30-348 Kraków, Polska e-mail: wojciech.sadkowski@uj.edu.pl 